\title{
RELATIONSHIP BETWEEN NITRIC OXIDE, ENZYMATIC ANTIOXIDANT SYSTEM AND ABA IN MAIZE UNDER LONG-TERM DROUGHT
}

\author{
PAULO CÉSAR MAGALHÃES ${ }^{1}$, ALYNE OLIVEIRA LAVINSKY ${ }^{1}$, \\ HEVERTON FERNANDO MELO' ${ }^{1}$ JUNIA CLARISSA ALVES ${ }^{1}$, \\ THIAGO CORRÊA DE SOUZA², ALICE PITA BARBOSA ${ }^{3}$ e CLEBERSON RIBEIRO ${ }^{3}$
}

${ }^{1}$ Embrapa Milho e Sorgo, Sete Lagoas, MG, paulo.magalhaes@embrapa.br, alynelavinsky@gmail.com,hevertonfernando@gmail.com,juniaclarissaalves@gmail.com

${ }^{2}$ Universidade Federal de Alfenas, Alfenas, MG, thiagonepre@hotmail.com

${ }^{3}$ Universidade Federal de Viçosa, Viçosa, MG, pitabarbosa@yahoo.com.br, cleberson.ribeiro@ufv.br

Revista Brasileira de Milho e Sorgo, v.14, n.2, p. 155-166, 2015

\begin{abstract}
The relationship between nitric oxide (NO) and up-regulation of the antioxidant system ABA-mediated in maize was evaluated under long-term drought. Two maize genotypes with contrasting drought tolerance (BRS1010 - sensitive and DKB390 - tolerant) were exposed to two soil water levels, field capacity (FC) and water deficit (WD) at pre-flowering. After 12 days under these conditions, plants were irrigated and soil water level kept at FC until harvest. The plants BRS1010 under water deficit (WD) showed lower catalase activity and reduced levels of NO, whereas ABA and malondialdehyde (MDA) levels increased compared to plants under FC. Although, DKB390 plants under WD did not present changes on the activity of enzymatic antioxidant system and ABA compared to plants at FC, and cellular damage remain unaltered; this fact was associated with the increase in NO levels. As a result, DKB390 plants under WD showed harvest index values 50\% higher than BRS1010 under the same condition.
\end{abstract}

Key words: DAF-2DA, catalase, mesophyll conductance, photoassimilate, harvest index.

\section{RELAÇÃO ENTRE ÓXIDO NÍTRICO, SISTEMA ANTIOXIDANTE ENZIMÁTICO E ABA EM MILHO SOB DÉFICIT HÍDRICO SEVERO}

\begin{abstract}
RESUMO - Avaliou-se a relação entre óxido nítrico (NO) e aumento na atividade de enzimas do sistema antioxidante induzido por ácido abscísico (ABA) em milho sob déficit hídrico severo. Para tanto, dois genótipos de milho contrastantes para tolerância à seca (BRS1010 - sensível e DKB390 - tolerante) foram cultivados sob irrigação e, ao atingirem o préflorescimento, foram expostos a dois níveis de água no solo (CC - capacidade de campo e DH - déficit hídrico). Após 12 dias nessas condições, a irrigação foi restabelecida de modo a manter o nível de água no solo sob CC até a colheita. Plantas do BRS1010 sob DH tiveram a atividade da enzima catalase e os níveis de NO diminuídos, enquanto os níveis de $\mathrm{ABA}$ e de malonaldeido (MDA) foram aumentados em relação às suas respectivas plantas sob CC. Por sua vez, plantas do DKB390 sob DH não apresentaram variações na atividade de enzimas do sistema antioxidante, tampouco nos níveis de $\mathrm{ABA}$ em relação às suas respectivas plantas sob $\mathrm{CC}$, e ainda assim os níveis de MDA não foram alterados; fato acoplado a aumentos nos níveis de NO. Consequentemente, sob DH, as plantas oriundas do DKB390 apresentaram valores 50\% maiores de índice de colheita em relação às dos BRS1010.
\end{abstract}

Palavras-chave: DAF - 2DA, catalase, condutância do mesofilo, fotoassimilados, índice de colheita. 
Maize (Zea mays L.) is a species that presents high water consumption, and stomatal closure is one of the first responses under water deficit (WD) condition, which limits the leaf gas exchange and, consequently, productivity (Souza et al., 2013). This fact occurs because reduction in soil water potential with the occurrence of WD induces the biosynthesis of signaling molecules in dehydrated roots, especially abscisic acid (ABA). This sign is emitted and transmitted to leaves where its accumulation prevents decrease in leaf water status via stomatal closure (Benesová et al., 2012), and thus induces the increase of the activity of enzymes of the antioxidant system (Souza et al. 2014).

Analysis of early-term drought in maize by Souza et al. (2014) showed that stomatal conductance to water vapor $\left(g_{\mathrm{s}}\right)$ declined with the decrease of water status, which invariably coincided with the decrease in the photosynthetic rate $(A)$ and transpiration (E). Furthermore, these authors proposed that $A$ improvements in maize genotypes tolerant to WD occur, in a greater extent, by controlling the oxidative stress by increasing the activity of enzymes of the antioxidant system in leaves, being this process induced by the increase in ABA levels.

As drought progress, the levels of reactive oxygen species (ROS) potentially able to cause lipid peroxidation (Chugh et al., 2011) increases, impairing $A$ and yield due to the decline in the enzyme activity of the antioxidant system and ABA levels (Souza et al. 2014). Several evidences suggest that nitric oxide (NO) is also an important signaling molecule involved in mechanisms of defense in response to long-term drought, by inducing ABA biosynthesis (Zhao et al., 2001; Xing et al., 2004; Zhang et al, 2011) and reducing damage at membrane level and mesophyll cells (Jie et al, 2012; Zhuk \& Musiyenko, 2012).

Recent studies have suggested that NO is also involved in enhancing the enzyme activity mediated by ABA antioxidant system such as superoxide dismutase (SOD), catalase (CAT) and ascorbate peroxidase (APX) (Zhou et al., 2005; Shi et al., 2014). However, it has been observed the action of NO inhibiting the expression and activity of these enzymes (Clark et al., 2000; Murgia et al., 2004). Further evidences are required to find out the involvement of $\mathrm{NO}$ in the increasing of the activity of enzymes of the antioxidant system ABA-mediated. Apparently, increases in ABA levels when plants are exposed to long-term drought occur at the expense of basal levels depletion of NO in plant tissues (LozanoJuste \& Leon, 2010), or in the absence of other tolerance mechanism.

The objective of this study was to evaluate the relationship between NO and the up-regulation of enzymes of the antioxidant system ABA-mediated in maize under long-term drought.

\section{Material and Methods}

\section{Plant material, cultivation conditions and experimental design}

The experiment was carried out in a greenhouse at National Maize and Sorghum

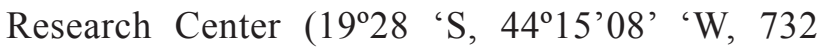
$\mathrm{m})$, and the plant material consisted of two maize genotypes, one tolerant (DKB 390) and one sensitive (BRS 1010). The choice of genotypes was based on previous results from a field experiment carried out by researchers from the breeding program of National Maize and Sorghum Research 
Center, which has accumulated experience in maize phenotyping for drought tolerance.

Plants were grown in plastic pots containing $20 \mathrm{~kg}$ typical dystrophic Red Latosol. The water content in the soil was daily monitored between 09:00 a.m. and 03:00 p.m., with a moisture sensors model GB Reader N1535 (Measurement Engineering, Australia) installed in the center of each pot with the aid of a screw auger, to a depth of $20 \mathrm{~cm}$. These sensors detect the water content in the soil based on electrical resistance and are coupled to digital meters. Water replacement by irrigation was based on the data obtained with the sensor and was added to reach FC during the period preceding the imposition of the treatments. The water replacement calculations were performed with the aid of a spreadsheet, based on soil water retention curve. The required cultivation and phytosanitary treatments were performed.

At the pre-flowering growth stage, half of each initial treatment was subjected to water deficit (WD); the other half continued to receive daily irrigation in order to maintain soil moisture close to field capacity (FC), with soil water tension of $-18 \mathrm{kPa}$. WD occurred by daily providing $50 \%$ of the total available water until the soil water tension reaches at least $-138 \mathrm{kPa}$. After twelve days under this condition, physiological evaluations were performed as mentioned below.

Gas exchange and the fluorescence of chlorophyll $a$ weremeasured in leaves corresponding to the ear insertion with an infrared gas analyzer (IRGA - Infrared Gas Analyzer) Model 6400 LI (LI-COR, Lincoln, NE, USA) equipped with a fluorometer (LI 6400-40, LI-COR Inc.) (Souza et al., 2013). Samples of leaves were collected and stored in liquid nitrogen for determination of antioxidant enzymes activity, levels of abscisic acid (ABA) and nitric oxide (NO), as well as cellular damage based on malondialdehyde (MDA) accumulation. Then, the water supply was restored and maintained at optimum levels by the end of the cycle, when agronomic parameters associated with productivity were measured. The experimental unit was the pot containing two plants, with six replications per treatment.

Preliminary statistical tests were used to adjust the results of the analysis of variance (ANOVA). The Scott-Knott test at 5\% probability was used to test any contrast.

\section{Enzymatic assays}

The activity of the enzymes of the antioxidant system, named dismutase superoxide (SOD, EC 1.15.1.1), catalase (CAT, EC 1.11.1.6) and ascorbate peroxidase (APX, EC 1.11.1.11), was determined from the plant material extracted in a medium containing potassium phosphate buffer $0.1 \mathrm{M}(\mathrm{pH}$ 6.8), 0.1 mM EDTA, 1 mM DTT, 1 mM PMSF and $1 \%$ PVPP (w/v). Total SOD activity was determined by measuring the ability to inhibit the photochemical reduction of $p$-nitro-blue-tetrazolium chloride at $560 \mathrm{~nm}$. The activity of CAT was estimated by measuring the rate of decomposition of $\mathrm{H}_{2} \mathrm{O}_{2}$ at 240 $\mathrm{nm}$, while total APX activity was determined by monitoring the decline in absorbance at $290 \mathrm{~nm}$. The levels of ABA quantification was performed using immunoenzymatic assay kits (Phytodetec ABA Enzyme Immunoassay Test Kit-SigmaAldrich). The MDA accumulation was estimated as the content of total 2-thiobarbituric acid-reactive substances. Additional details are described in Souza et al. (2014). 


\section{Detection of $\bullet N O$ by confocal laser scanning microscopy (CLSM)}

-NO was detected in lateral root tips with 10 M 4-aminomethyl 2,7 difluorofluorescein diacetate (DAF-2 DA, Sigma,St. Louis, MO, USA) prepared in $10 \mathrm{mM}$ Tris- $\mathrm{HCl}(\mathrm{pH}$ 7.4). The samples were examined with a confocal laser scanning microscope (Leica TCS SL, Leica Microsystems, HeidelbergGmbH, Wetzlar, Germany).

\section{Photosynthetic}

\section{gas exchange measurements}

The photosynthetic rate $(A)$, stomatal conductance to water vapor $\left(g_{\mathrm{s}}\right)$, substomatal $\mathrm{CO}_{2}$ concentrations $\left(C_{\mathrm{i}}\right)$ and transpiration rate $(E)$ were measured simultaneously with chlorophyll $a$ fluorescence parameters from 10:00 a.m. to 1:00 p.m., when $A$ is at its maximum, under artificial $P P F D$ of $1500 \mu \mathrm{mol}$ photons $\mathrm{m}^{-2} \mathrm{~s}^{-1}$ at the leaf level, $400 \mathrm{~mol}$ $\mathrm{CO}_{2}$ mol air ${ }^{-1}$ and $21 \% \mathrm{O}_{2}$. During the measurements, the leaf-to-air vapor pressure deficit was ca $1.0 \mathrm{kPa}$ and leaf temperature of $25^{\circ} \mathrm{C}$. The equipment was programmed to make curves $A / C_{\mathrm{i}}$ varying sequentially $\mathrm{CO}_{2}$ partial pressure: 40, 30, 20, 10, 5, 40, 60, 80, 100 , 120,140 and $160 \mathrm{~Pa}$. Estimations of $g_{\mathrm{m}}$ were performed using the combined gas exchange/fluorescence data (Harley et al., 1992). $A-C_{\mathrm{i}}$ curves were converted into $A-C_{\text {c }}$ curves to estimate the maximum rate of carboxylation of Ribulose 1,5 bisphosphate (Rubisco, $V_{\text {cmax }}$ ) and phospoenolpyruvate (PEPc, $V_{\text {pmax }}$ ), as well as the maximum rate of carboxylation limited by electron transport $\left(J_{\max }\right)$ (Massad et al., 2007). Rates of ATP and NADPH consumption, as well as $\mathrm{H}^{+}$ requirement were estimated based on von Caemmerer (2000). Additionally, nitrogen (N) allocated in the photosynthetic machinery was accessed as Niinemets et al. (1997).

\section{Agronomic parameters}

At harvesting, plants were partitioned into roots, stems, leaves, tassels, ears (cob, straw and grains), and dried in oven with forced air circulation at $70^{\circ} \mathrm{C}$ for $72 \mathrm{~h}$. It was evaluated the harvest index, number of grains per ear and weight of 100 grains (Souza et al., 2013).

Additionally, a group of 50 grains was subjected to morphometric characterization, by measuring the dimensions of the grains (length, width and thickness) using a digital caliper rule, with three replications per treatment. Subsequently, these grains were soaked overnight in ethylenediamine $(10 \%, \mathrm{w} / \mathrm{v})$ and longitudinally cut by a knife to evaluate possible changes in embryo size, depending on the treatment. Photographs were obtained using a stereoscopic microscope and the ImageJ program was used to calculate the ratio between the areas of the endosperm and the embryo.

\section{Results and Discussion}

The activity of SOD was not significantly different between the genotypes and soil water levels (data not shown). With exposure to WD, APX activity also remained unchanged, while CAT decreased only in BRS1010 genotype; in this genotype the decrease in CAT activity was followed by significant increase in the levels of ABA and MDA (Figure 1). Plants DKB390 under WD had no significant changes in the activity of enzymes of the antioxidant system, either in ABA levels related to their respective plants in $\mathrm{FC}$, and still MDA levels were not increased (Figure 1). 

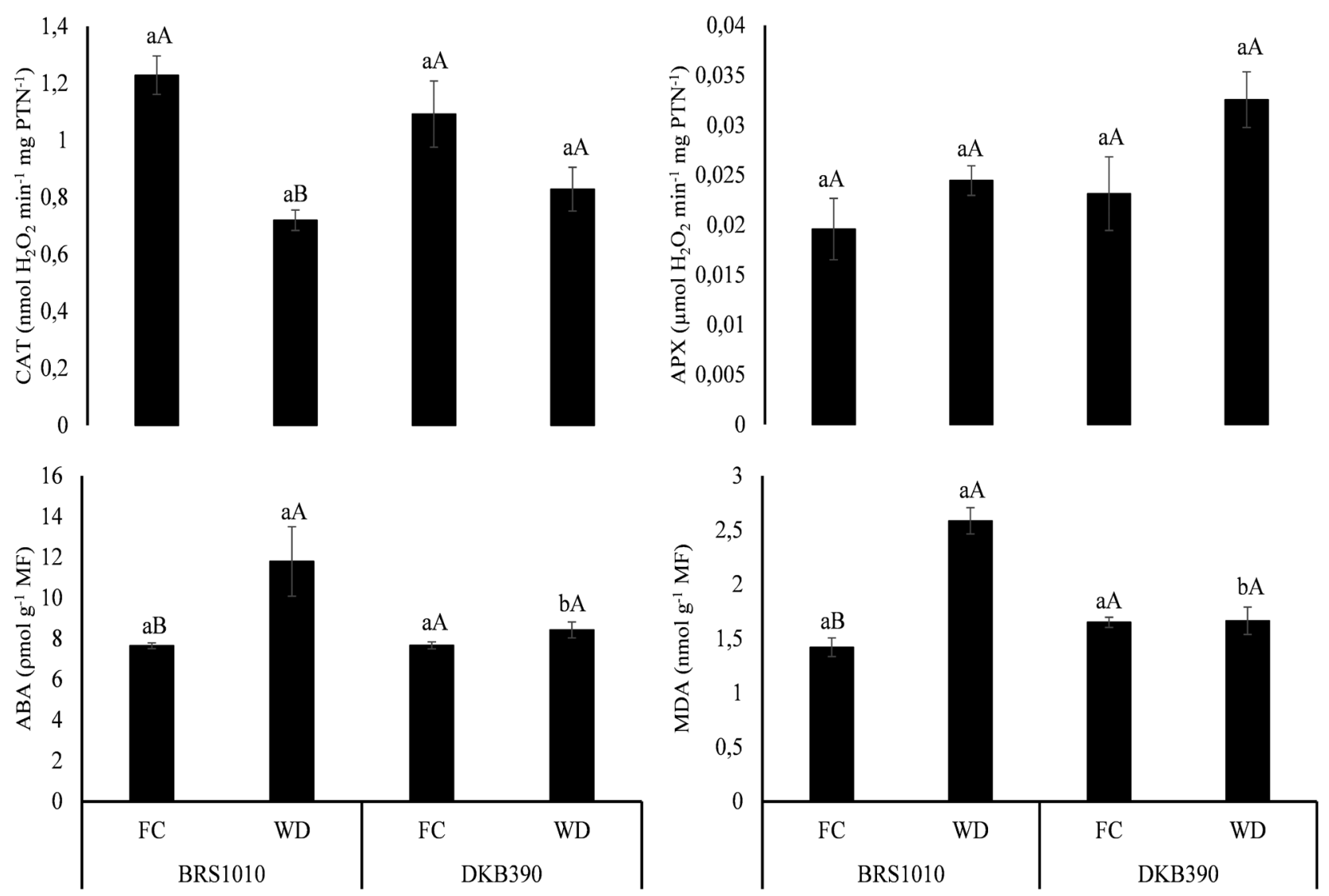

FIGURE 1. Activity of antioxidant enzymes catalase (CAT) and ascorbate peroxidase (APX), and levels of abscisic acid content (ABA) and malondialdehyde (MDA) in leaves of maize genotypes with contrasting drought tolerance (BRS1010-sensitive and DKB390-tolerant), cultivated under two different soil water levels (FC-field capacity and WD-water deficit). Means followed by the same letter are not statistically different from each other. Lowercase letters denote comparisons between genotypes within the same soil water level, and uppercase letters denote comparisons between the soil water levels within the same genotype. Means were compared by Scott-Knott test at 5\% probability.

Through the analysis of cross-sections of the leaf with confocal microscopy to laser using a fluorescent probe sensitive to NO (DAF-2DA) it was possible to detect the presence of NO in xylem vessel elements, sclerenchyma and epidermal cells, despite the genotype and soil water level.
However, under WD the production of NO derived from green fluorescent labeling with DAF-2DA in BRS1010 genotype decreased. In turn, plants DKB390 under WD showed increased fluorescence of DAF-2DA in the leaves tissues when compared to plants under FC (Figure 2). 

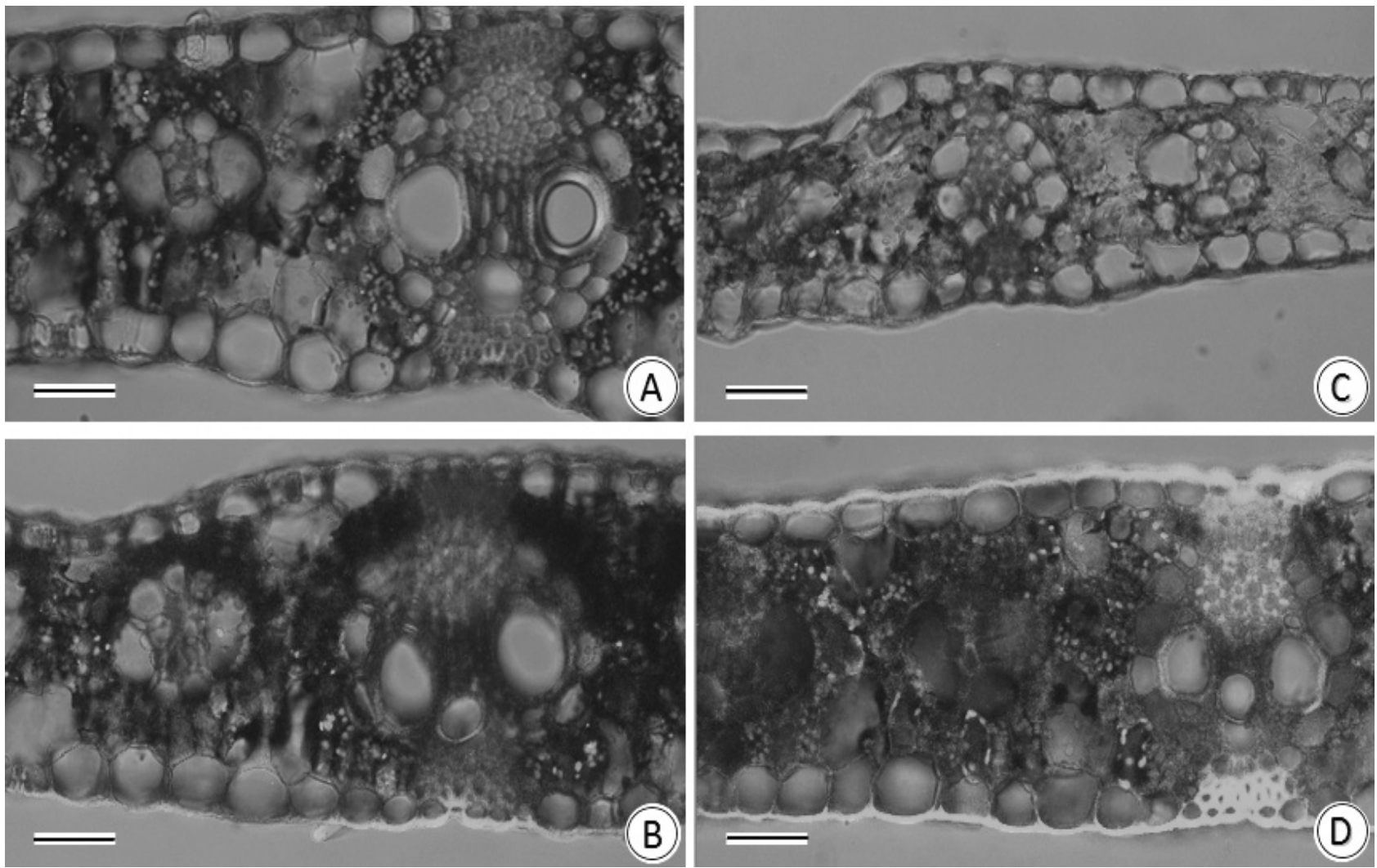

FIGURE 2. Confocal laser scanning microscope analysis for NO using probe DAF-2DA in leaves of maize genotypes with contrasting drought tolerance (BRS1010-sensitive and DKB390-tolerant), cultivated under two different soil water levels (FC-field capacity and WD-water deficit). A) BRS1010 under FC; B) DKB390 under FC; C) BRS1010 under WD; D) DKB390 under WD. Barr: $50 \mu \mathrm{m}$.

Under $\mathrm{FC}$, the values of $A, \mathrm{~g}_{\mathrm{s}}, \mathrm{V}_{\mathrm{p}, \max }, \mathrm{V}_{\mathrm{c}}$, max and $\mathrm{J}_{\max }$ were higher in DKB390 compared to BRS1010, while the values of $C_{i}$ and $C_{c}$ were smaller. The $F_{v} / F_{m}, E, g_{m}$ and $P R$ values did not change (Table 1).

Irrespective of genotype, there was a significant reduction of $A, g_{\mathrm{s}}, E, F_{\mathrm{v}} / F_{\mathrm{m}}, V_{\mathrm{p}, \max ,} V_{\mathrm{c} \text {,max, }}$ $J_{\max }$ and $A / E$ in in plants exposed to the stress caused by WD compared to those who had the soil moisture maintained close to $\mathrm{FC}$, whereas $C_{\mathrm{i}}, C_{\mathrm{c}}$ and $P R$ values increased. However, plants DKB390 under WD showed $A, g_{\mathrm{s}}, E, g_{\mathrm{m}}, P R, V_{\mathrm{p}, \max }, V_{\mathrm{c}, \max ,} J_{\text {max }}$ and $A / E$ values higher than BRS1010 under the same condition (Table 1). Only plants BRS1010 showed very low $A$ values under WD due to additional $g_{\mathrm{m}}$ limitation, which associated with a low $E$ value resulted in extremely low efficiency in water use $(A / E)$ (Table 1). 
TABLE 1. Leaf gas exchange obtained in situ and derived from A-Cc curves in leaves of maize genotypes with contrasting drought tolerance (BRS1010-sensisitive and DKB390-tolerant), cultivated under two different soil water levels (FC-field capacity and WD-water deficit). Each data were obtained from the leaf above the ear $(n=6) .^{1}$

\begin{tabular}{|c|c|c|c|c|}
\hline \multirow[t]{2}{*}{ Parameter } & \multicolumn{2}{|c|}{ BRS1010 } & \multicolumn{2}{|c|}{ DKB 390} \\
\hline & $\mathrm{FC}$ & WD & $\mathrm{FC}$ & WD \\
\hline $\mathrm{A}^{2}$ & $23,20 \mathrm{bA}^{2}$ & $0,152 \mathrm{bB}$ & $27,72 \mathrm{aA}$ & $2,257 \mathrm{aB}$ \\
\hline $\mathrm{F}_{\mathrm{v}} / \mathrm{F}_{\mathrm{m}}$ & $0,803 \mathrm{aA}$ & $0,762 \mathrm{aB}$ & $0,800 \mathrm{aA}$ & $0,757 \mathrm{aB}$ \\
\hline $\mathrm{g}_{\mathrm{s}}$ & $0,102 \mathrm{bA}$ & $0,007 \mathrm{bB}$ & $0,138 \mathrm{aA}$ & $0,023 \mathrm{aB}$ \\
\hline $\mathrm{E}$ & $2,107 \mathrm{aA}$ & $0,088 \mathrm{bB}$ & $2,347 \mathrm{aA}$ & $0,499 \mathrm{aB}$ \\
\hline $\mathrm{C}_{\mathrm{i}}$ & $75,27 \mathrm{aB}$ & $357,8 \mathrm{aA}$ & $43,38 \mathrm{bB}$ & $215,5 \mathrm{bA}$ \\
\hline $\mathrm{g}_{\mathrm{m}}$ & 55,17 aA & $0,830 \mathrm{bB}$ & $61,62 \mathrm{aA}$ & 83,79 aA \\
\hline $\mathrm{C}_{\mathrm{c}}$ & $63,67 \mathrm{aB}$ & $357,8 \mathrm{aA}$ & $29,52 \mathrm{bB}$ & $214,4 \mathrm{bA}$ \\
\hline PR & $-1,91 \mathrm{aB}$ & $0,619 \mathrm{bA}$ & $-2,63 \mathrm{aB}$ & $1,122 \mathrm{aA}$ \\
\hline$V_{\text {pmax }}$ & $38,26 \mathrm{bA}$ & $12,54 \mathrm{bB}$ & $42,60 \mathrm{aA}$ & $14,94 \mathrm{aB}$ \\
\hline $\mathrm{V}_{\text {cmax }}$ & $64,84 \mathrm{bA}$ & $50,66 \mathrm{bB}$ & $67,60 \mathrm{aA}$ & $52,03 \mathrm{aB}$ \\
\hline $\mathrm{J}_{\max }$ & $231,8 \mathrm{bA}$ & $71,29 \mathrm{bB}$ & $260,0 \mathrm{aA}$ & $81,56 \mathrm{aB}$ \\
\hline $\mathrm{A} / \mathrm{E}$ & $11,99 \mathrm{aA}$ & $1,645 \mathrm{bB}$ & $11,81 \mathrm{aA}$ & $4,592 \mathrm{aB}$ \\
\hline
\end{tabular}

${ }^{1}$ Abbreviations: photosynthetic rate $\left(A, \mu \mathrm{mol} \mathrm{CO} \mathrm{m}^{-2} \mathrm{~s}^{-1}\right)$, maximal efficiency of photosystem II $\left(F_{\mathrm{v}} / F_{\mathrm{m}}\right)$, stomatal conductance to water vapor $\left(g_{\mathrm{s}}, \mathrm{mol} \mathrm{H}_{2} \mathrm{O} \mathrm{m}^{-2} \mathrm{~s}^{-1}\right)$, transpiration rate $\left(E, \mathrm{molH}_{2} \mathrm{O} \mathrm{m}^{-2} \mathrm{~s}^{-1}\right)$, internal $\mathrm{CO}_{2}$ concentration $\left(C_{\mathrm{i}}, \mu \mathrm{mol} \mathrm{CO}_{2} \mathrm{~m}^{-2} \mathrm{~s}^{-1}\right)$, mesophyll conductance $\left(g_{\mathrm{m},}\right.$ mol CO $\left.\mathrm{CO}^{-2} \mathrm{~s}^{-1}\right), \mathrm{CO}_{2}$ concentration in chloroplast $\left(C_{\mathrm{c}} \mu \mathrm{mol} \mathrm{mol}^{-1}\right)$, photorespiratory rate $\left(F R, \mu \mathrm{mol} \mathrm{CO} \mathrm{CO}^{-2}\right.$

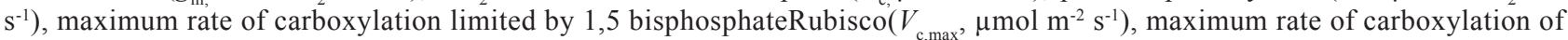

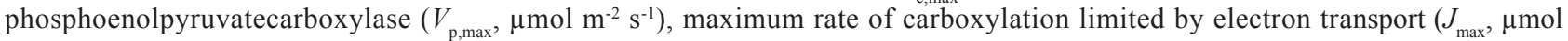
$\left.\mathrm{m}^{-2} \mathrm{~s}^{-1}\right)$, water use efficiency $(A / E)$.

${ }^{2}$ Means followed by the same letter are not statistically different from each other. Lowercase letters denote comparisons between genotypes within the same soil water level, and uppercase letters denote comparisons between the soil water levels within the same genotype. Means were compared by Scott-Knott test at 5\% probability.

Under WD plants DKB390 showed, higher mass and number of grains per ear (Figure 3), compared to BRS1010, without alteration in total biomass (data not shown). Consequently, the HI in plants DKB390 under FC was 50\% higher than in BRS1010 (Figure 3). Only BRS1010 plants under WD presented declined EM:E values compared to FC (Figure 3), corroborating a lower photoassimilates flux in this maize genotype under WD. 

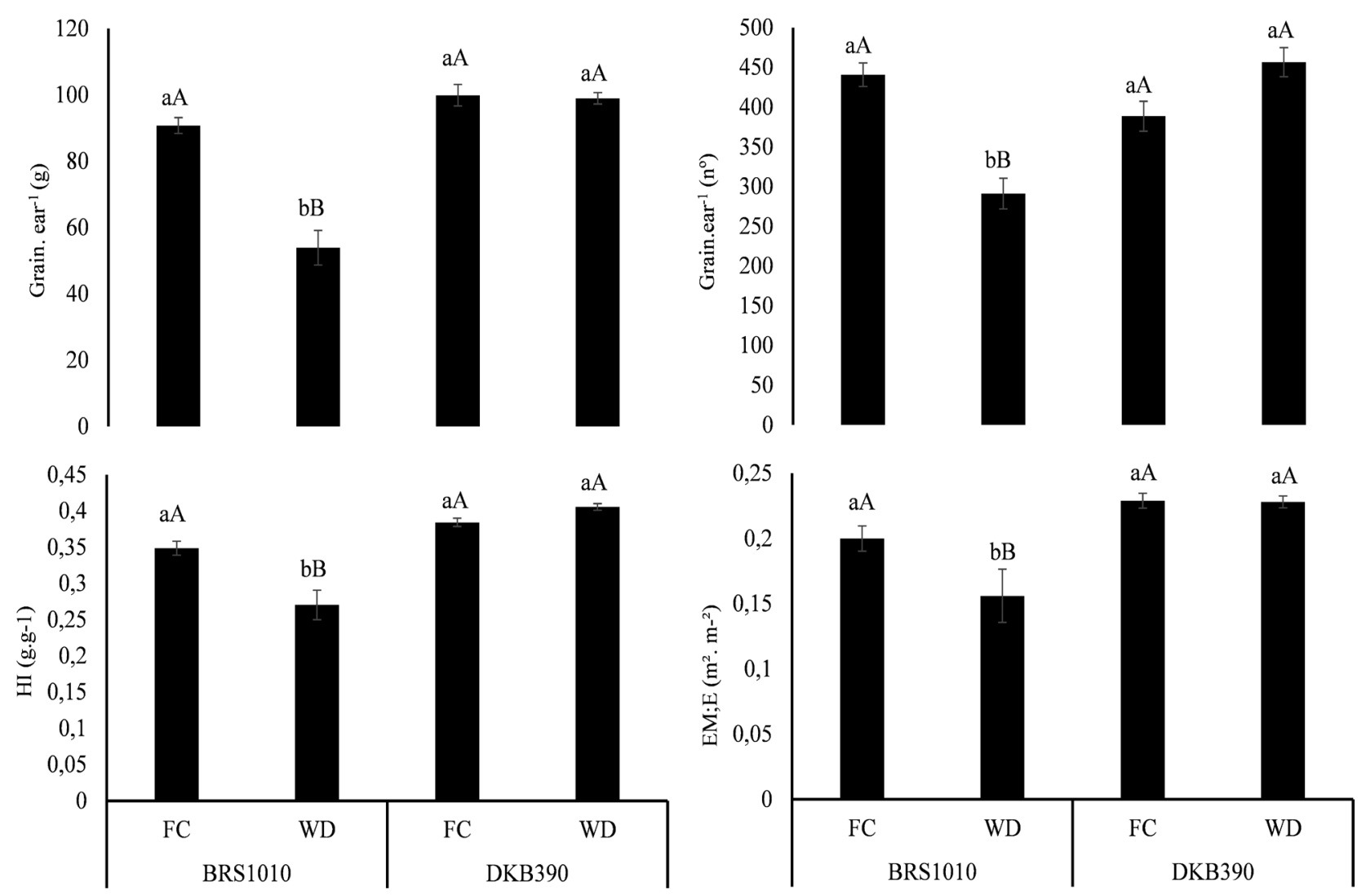

FIGURE 3. Agronomic performance in maize genotypes with contrasting drought tolerance (BRS1010sensitive and DKB390-tolerant), cultivated under two different soil water levels (FC-field capacity and WDwater deficit). Means followed by the same letter are not statistically different from each other. Lowercase letters denote comparisons between genotypes within the same soil water level, and uppercase letters denote comparisons between the soil water levels within the same genotype. Means were compared by Scott-Knott test at $5 \%$ probability.

The tolerance to oxidative stress associated with WD, is greatly due to the induction of increased SOD activity, which converts $\bullet \mathrm{O}_{2}$ into $\mathrm{H}_{2} \mathrm{O}_{2}$, and subsequent increase in the activity of other enzymes such as CAT and APX, removing the formed product; the ABA induction controls such increase (Bano et al, 2012; Souza et al, 2014; Cai et al, 2015). In this study, the level of oxidative damage associated with WD was evident only in the BRS1010 genotype. In previous studies, the genotype DKB390 behaved like tolerant WD (Souza et al., 2014) and it was expected on plants of this genotype increases in ABA levels and activity of enzymes of the antioxidant system, and a smaller content of MDA, indicating an increase in the antioxidant capacity and little damage at the membrane level. Surprisingly, plants DKB390 under WD showed no significant peroxidative damage in the membrane, without the need for adjustments in the activity of antioxidant enzymes ABA-mediated. 
Souza et al. (2014) observed that the activity of antioxidant enzymes is high during the first days under WD, but after ten days under such stressful condition the activity of antioxidant enzymes decreases, confirming the results of this study in which the plants were exposed to WD for 12 days. Possibly, not only the CAT enzyme but also the ABA have been disabled due to long exposure to WD, and other mechanisms of tolerance to WD, except the increase in enzyme activity of the antioxidant system mediated by ABA, were activated to control oxidative processes only in plants DKB390 under WD. Only plants BRS1010 under WD presented increased ABA levels compared to the respective control under FC. However, due to inactivation of the enzyme antioxidant defense system and other protection mechanisms against oxidative damage, MDA levels increased greatly. In fact, the increase in ABA levels occurs only if there is a depletion of basal levels of NO (Lozano-Juste and Leon, 2010).

The role of NO in oxidative stress tolerance mechanism under WD has not been elucidated (Xing et al., 2004; Zhang et al, 2011). Several authors have shown that both NO and ROS induce ABA biosynthesis during WD (Zhao et al., 2001; Xing et al, 2004), but the signaling pathway for $\mathrm{NO}$ is different from that widely accepted for ROS (Xing et al., 2004). Recently, Jie et al. (2012) showed that increased NO level reduces damage to the membrane by decreasing $E$ in leaves of rice plants under WD. Notably, the plants BRS1010 under WD closed stomata to preventing loss of latent heat via $E$, and did not invest in the production of NO, causing an increase in leaf temperature followed by damage to the photochemical step of photosynthesis. With photochemical damage, the availability of NADPH and ATP for use by carbon reduction and phosphorylation enzymes at biochemical step were affected, thereby explaining the increase in $C_{i}$ and the very low $A$ values compared to plants of that genotype under FC. The low $A$ values, associated with also lower $E$ values resulted in lower $A / E$. In addition, only BRS1010 plants under WD showed $g_{\mathrm{m}}$ limitation.

According to Souza et al. (2013), the maintenance of a high yield in drought tolerant genotype under WD is related to increase in $E$ which, in turn, occurs at the expense of higher water consumption. By releasing more water via stomatal opening, there would be a leaf cooling, which would prevent photochemical damage. Plants DKB390 under WD also limited $E$ and $g_{\text {s }}$ showing photochemical damage; however, $g_{\mathrm{m}}$ was not limited suggesting that $g_{\mathrm{m}}$ offset reductions in $g_{\mathrm{s}}$ in plants DKB390 under WD. Hommel et al. (2014) showed the importance of $g_{\mathrm{m}}$ in the optimization of resources in water restriction periods, and Zhuk \& Musiyenko (2012) proposed that NO reduces the destructive effects of oxidative stress in the mesophyll cells in wheat plants under WD, although the role of $g_{\mathrm{m}}$ has not been considered.

In previous studies conducted by the research group, it was observed that the $\mathrm{N}$ invested in the photosynthetic apparatus for carboxylation enzymes, electron transport chain and the complex collector of light in the photosystem was reduced in plants of BRS1010 and DKB390 under WD. Only plants of BRS1010 genotype under WD had the $g_{\mathrm{m}}$ limited by low investment in N. Perhaps the DKB390 under $\mathrm{DH}$ only decreased the $g_{\mathrm{s}}$ by the need to limit $E$ and prevent embolism in the xylem which, in turn, favored the $\mathrm{N}$ deviation from enzymes invested in the photosynthetic apparatus not only for the construction of aquaporins, and other proteins that contribute to $g_{\mathrm{m}}$, but also for costs associated with its maintaining (Cowan, 1986). 
The increase in gene expression and abundance of aquaporins in bean leaves under WD are correlated with the decline in $E$ due to stomatal closure induced by ABA and increased $g_{\mathrm{m}}$ (Aroca et al., 2006). Parent et al. (2009) suggested that ABA affects hydraulic properties of plants by increasing the abundance of aquaporins, which contribute to the maintenance of leaf water status. Some aquaporins, however, are little affected by $\mathrm{ABA}$ (Xu et al., 2013), and NO induces increases in the expression of genes encoding aquaporins (Liu et al., 2007; Di Pietro et al., 2013). It is suggested therefore that NO induces the expression of genes encoding aquaporin in DKB390 under WD which, in turn, regulates $g_{\mathrm{m}}$ to avoid damage at the membrane level, at least when the antioxidant enzyme system defense mediated by ABA is disabled. Analysis of agronomic characters confirmed tolerance and sensitivity, respectively, of DKB390 and BRS1010 under WD.

\section{Conclusion}

The tolerance to drought in DKB390 genotype is associated with increased levels of NO, offsetting the loss in enzyme activity of the antioxidant system mediated by ABA.

\section{Acknowledgement}

To the Minas Gerais State Research Foundation (FAPEMIG), by BPD-00477-13 grant for Alyne Oliveira Lavinsky;

To the Nucleus of Microscopy and Microanalysis at the "Universidade Federal de Viçosa, UFV" (www.nmm.ufv.br), where microscopy analysis were performed.

\section{References}

AROCA，R.; FERRANTE，A.; VERNIERI，P.; CHRISPEELS, M. J. Drought, abscisic acid and transpiration rate effects on the regulation of PIP aquaporin gene expression and abundance in Phaseolus vulgaris Plants. Annals of Botany, London, v. 98, n. 6, p. 1301-1310, 2006.

BANO, A.; ULLAH, F.; NOSHEEN, A. Role of abscisic acid and drought stress on the activities of antioxidant enzymes in wheat. Plant Soil and Environment, Prague, v. 58, n. 4, p. 81-185, 2012.

BENESOVÁ, M.; FISCHER, L.; HNLICKA, F.; WILHELMOVÁ, N.; ROTHOVÁ, M.; PROCHÁZKOVÁ, D.; HONNEROVÁ, J.; FRIDRICHOVÁ, L.; HNLICKOVÁ, H. The physiology and proteomics of drought tolerance in maize: early stomatal closure as a cause of lower tolerance to short-term dehydration? Plos One, San Francisco, v. 7, n. 6, p. e38017, 2012. CAI, S.; JIANG, G.; YE, N.; CHU, Z.; XU, XUEZHONG; ZHANG, J.; ZHU, G. A key ABA catabolic gene, OsABA8ox3, is involved in drought stress resistance in rice. Plos One, San Francisco, v. 10, n. 2, p. e0116646, 2015.

CHUGH, V.; KAUR, N.; GUPTA, A. Evaluation of stress oxidative tolerance in maize (Zea mays L.) seedlings in response to drought. Indian Journal of Biochemistry and Biophysics, New Delhi, v. 48, p. 47-53, 2011.

CLARKE, A.; DESIKAN, R.; HURST, R. D.; HANCOCK, J. T.; NEILL, S. J. No way back: nitric oxide and programmed cell death in Arabidopsis thaliana suspension cultures. Plant Journal, Oxford, v. 24, n. 5, p. 667-677, 2000. 
COWAN, I. R. Economics of carbon fixation in higher plants. In: GIVNISH, T. J. On the Economy of Plant Form and Function. Cambridge: Cambridge University, 1986. p 133-176, 1986.

DI PIETRO, M.; VILARET, J.; LI, G-W.; HEM, S.; PRADO, K.; ROSSIGNOL, M.; MAUREL, C.; SANTONI, V. Coordinated post-translational responses of aquaporins to abiotic and nutritional stimuli in Arabidopsis Roots. Molecular \& Cellular Proteomics, Rockville, v. 12, p. 38863897, 2013.

HARLEY, P. C.; LORETO, F.; DI MARCO, G.; SHARKEY, T. D. Theoretical considerations when estimating mesophyll conductance to $\mathrm{CO}_{2}$ flux by analysis of the response of photosynthesis to $\mathrm{CO}_{2}$. Plant Physiology, Bethesda, v. 98, p. 1429-1436, 1992.

HOMMEL, R.; SIEGWOLF, R.; SAURER, M.; FARQUHAR, G. D.; KAYLER, Z.; FERRIO, J. P.; GESSLER, A. Drought response of mesophyll conductance in forest understory species-impacts on water-use efficiency and interactions with leaf water movement. Plant Physiology, Bethesda, v. 152, p. 98-114, 2014.

JIE, X.; LONG, Z.; GUANFU, F.; YONGJIE, Y.; CHENG, Z.; LONGXING, T. Droughtinduced proline accumulation is uninvolved with increased nitric oxide, which alleviates drought stress by decreasing transpiration in rice. Journal of Plant Research, Tokyo, v. 125, p. 155, 2012.

LIU, H.-Y.; YU, X.; CUI, D.-Y.; SUN, M. H.; SUN, W.-N.; TANG, Z-C.; KWAK, S.-S.; SU, W-A. The role of water channel proteins and nitric oxide signaling in rice seed germination. Cell Research, Beijing, v. 17, p. 638-649, 2007.
LOZANO-JUSTE, J.; LEÓN, J. Nitric oxide modulates sensitivity to ABA. Plant Signal Behavior, London, v. 3, p. 314-316, 2010.

MASSAD, R. S.; TUZET, A.; BETHENOD, O. The effect of temperature on $\mathrm{C}_{4}$-type leaf photosynthesis parameters. Plant, Cell and Environment, Oxford, v. 30, p. 1191-1204, 2007.

MURGIA, I.; DE PINTO, M. C.; DELLEDONNE, M.; SOAVE, C.; DE GARA, L. Comparative effects of various nitric oxide donors on ferritin regulation, programmed cell death, and cell redox state in plant cells. Journal of Plant Physiology, Stuttgart, 161: 777-783, 2004. NIINEMETS, Ü.; TENHUNEN, J. D. A model separating leaf structural and physiological effects on carbon gain along light gradients for the shade-tolerant species Acer saccharum. Plant Cell Environ Oxford, 20: 845-866, 1997.

PARENT, R.; HACHEZ, C.; REDONDO, E.; SIMONNEAU, T.; CHAUMONT, F.; TARDIEU, F. Drought and abscisic acid effects on aquaporin content translate into changes in hydraulic conductivity and leaf growth rate: a trans-scale approach. Plant Physiology, Bethesda, v. 149, p. 2000-2012, 2009.

SHI, H.; YE, T.; ZHU, J.; CHAN, Z. Constitutive production of nitric oxide leads to enhanced drought stress resistance and extensive transcriptional reprogramming in Arabidopsis. Journal of Experimental Botany, London, v. 65, p. 4119-4131, 2014.

SOUZA, T.C.;CASTRO,E.M.;MAGALHÃES, P.C.; LINO, L. O.; ALVES, E. T.; ALBUQUERQUE, P. Morphophysiology, morphoanatomy, and grain yield under field conditions for two maize hybrids with contrasting response to 
drought stress. Acta Physiologia Plantarum,

Warszowa, v. 35, p. 3201-3211, 2013.

SOUZA, T. C.; MAGALHÃES, P. C.; CASTRO, E. M.; CARNEIRO, N. P.; PADILHA, F. A.; GOMES-JR, C. C. ABA application to maize hybrids contrasting for drought tolerance: changes in water parameters and in antioxidant enzyme activity. Plant Growth Regulation, The Hague, v. 73, p. 205-217, 2014.

VON CAEMMERER, S. Biochemical Models of Leaf Photosynthesis. CSIRO Publishing Collingwood, Australia, 165p. 2000.

XING, H.; TAN, L.; AN, L.; ZHAO, Z.; WANG, S.; ZHANG, C. Evidence for the involvement of nitric oxide and reactive oxygen species in osmotic stress tolerance of wheat seedlings: inverse correlation between leaf abscisic acid accumulation andleaf water loss. Plant Growth

Regulation, The Hague, v. 42, p. 61-68, 2004. XU, C.; WANG, M.; ZHOU, L.; QUAN, T.; XIA, G. Heterologous Expression of the Wheat Aquaporin Gene TaTIP2;2 Compromises the Abiotic Stress Tolerance of Arabidopsis thaliana. Plos One, San Francisco, v. 8, p. e79618, 2013.

ZHANG, A.; ZHANG, J.; ZHANG, J.; YE, N.; ZHANG, H.; TAN, M.; JIANG, M. Nitric oxide mediates brassinosteroid-induced ABA biosynthesis involved in oxidative stress tolerance in maize leaves. Plant and Cell Physiology, Tokyo, v. 52, p. 181-192, 2011.

ZHAO, Z.; CHEN, G.; ZHANG, C. Interaction between reactive oxygen species and nitric oxide in drought-induced abscisic acid synthesis in root tips of wheat seedlings. Australian Journal of Plant Physiology, Melbourne, v. 28, p. 1055-1061, 2001.

ZHOU, B.; GUO, Z.; XING, J.; HUANG, B. Nitric oxide is involved in abscisic acid-induced antioxidant activities in Stylosanthes guianensis. Journal of Experimental Botany, London, v. 56, p. 3223-3228, 2005.

ZHUK, I. V.; MUSIYENKO, M. M. The influence of nitric oxide and mercury chloride on leaf mesophyll structure under natural drought conditions. Modern Phytomorphology, Lviv, v.1, p. 185-188, 2012. 